\title{
Managing Potential and Realized Absorptive Capacity: How do Organizational Antecedents matter?
}

\author{
Justin J.P. Jansen, Frans A.J. van den Bosch,
} Henk W. Volberda

\begin{tabular}{|l|l|}
\hline \multicolumn{2}{|l|}{ ERIM REPORT SERIES RESEARCH IN MANAGEMENT } \\
\hline ERIM Report Series reference number & ERS-2005-025-STR \\
\hline Publication & April 2005 \\
\hline Number of pages & 41 \\
\hline Persistent paper URL & http://hdl.handle.net/1765/6550 \\
\hline Email address corresponding author & jjansen @ rsm.nl \\
\hline Address & Erasmus Research Institute of Management (ERIM) \\
& RSM Erasmus University / Erasmus School of Economics \\
& Erasmus Universiteit Rotterdam \\
& P.O.Box 1738 \\
& 3000 DR Rotterdam, The Netherlands \\
& Phone: $\quad+31104081182$ \\
& Fax: $\quad+31104089640$ \\
& Email: info @erim.eur.nl \\
& Internet: $\quad$ www.erim.eur.nl \\
\hline
\end{tabular}

Bibliographic data and classifications of all the ERIM reports are also available on the ERIM website: www.erim.eur.nl 


\section{ERASMUS RESEARCH INSTITUTE OF MANAGEMENT}

REPORT SERIES

\section{RESEARCH IN MANAGEMENT}

\begin{tabular}{|c|c|}
\hline \multicolumn{2}{|c|}{ ABSTRACT AND KEYWORDS } \\
\hline Abstract & $\begin{array}{l}\text { This study explores how organizational antecedents affect potential and realized absorptive } \\
\text { capacity. Our study identifies differential effects for both components of absorptive capacity. } \\
\text { Results indicate that organizational mechanisms associated with coordination capabilities (i.e. } \\
\text { cross-functional interfaces, participation in decision-making, and job rotation) primarily enhance } \\
\text { a unit's potential absorptive capacity. Organizational mechanisms associated with socialization } \\
\text { capabilities (i.e. connectedness and socialization tactics) primarily increase a unit's realized } \\
\text { absorptive capacity. Our findings reveal why units may have difficulties in managing levels of } \\
\text { potential and realized absorptive capacity and vary in their ability to create value from their } \\
\text { absorptive capacity. }\end{array}$ \\
\hline Free Keywords & Combinative Capabilities, Absorptive Capacity, Organizational Antecedents, External Knowledge \\
\hline Availability & $\begin{array}{l}\text { The ERIM Report Series is distributed through the following platforms: } \\
\text { Academic Repository at Erasmus University (DEAR), DEAR ERIM Series Portal } \\
\text { Social Science Research Network (SSRN), SSRN ERIM Series Webpage } \\
\text { Research Papers in Economics (REPEC), REPEC ERIM Series Webpage }\end{array}$ \\
\hline Classifications & $\begin{array}{l}\text { The electronic versions of the papers in the ERIM report Series contain bibliographic metadata } \\
\text { by the following classification systems: } \\
\text { Library of Congress Classification, (LCC) LCC Webpage } \\
\text { Journal of Economic Literature, (JEL), JEL Webpage } \\
\text { ACM Computing Classification System CCS Webpage } \\
\text { Inspec Classification scheme (ICS), ICS Webpage }\end{array}$ \\
\hline
\end{tabular}




\title{
MANAGING PoTENTIAL AND REALIZED ABSORPTIVE CAPACITY: HOW DO ORGANIZATIONAL ANTECEDENTS MATTER?
}

\author{
JUSTIN J.P. JANSEN* \\ RSM Erasmus University
}

P.O. Box 1738

3000 DR Rotterdam, The Netherlands

Tel: +31 (0)104089782

Fax: +31 (0)104089013

E-mail: jjansen@rsm.nl

FRANS A.J. VAN DEN BOSCH

RSM Erasmus University

P.O. Box 1738

3000 DR Rotterdam, The Netherlands

Tel: +31 (0)104082005

Fax: +31 (0)104089013

E-mail: fbosch@rsm.nl

HENK W. VOLBERDA

RSM Erasmus University

P.O. Box 1738

3000 DR Rotterdam, The Netherlands

Tel: +31 (0)10 4082210

Fax: +31(0)104089013

E-mail: hvolberda@rsm.nl

\section{Accepted for Publication in The Academy of Management Journal}

\footnotetext{
* The authors thank Marshall Schminke and the three reviewers of $A M J$ for their constructive reviews. Comments from Alberto Aragón-Correa, Dania Dialdin, Arie Lewin, KC O'Shaughnessy, and Raymond van Wijk were very helpful for improving the overall quality of our manuscript. We thank Ad Druijts for enabling data collection at the financial services firm as well as Eric Tas and Susan de Grijp for research assistance. The Erasmus Research Institute of Management (ERIM) has supported this research.
} 


\title{
MANAGing Potential AND REALIZED AbSORPTIVE CAPACITY: How do ORganizATIONAL ANTECEDENTS MATTER?
}

\begin{abstract}
This study explores how organizational antecedents affect potential and realized absorptive capacity. Our study identifies differential effects for both components of absorptive capacity. Results indicate that organizational mechanisms associated with coordination capabilities (i.e. cross-functional interfaces, participation in decision-making, and job rotation) primarily enhance a unit's potential absorptive capacity. Organizational mechanisms associated with socialization capabilities (i.e. connectedness and socialization tactics) primarily increase a unit's realized absorptive capacity. Our findings reveal why units may have difficulties in managing levels of potential and realized absorptive capacity and vary in their ability to create value from their absorptive capacity.
\end{abstract}


The turbulence of the business environment has ensured focused attention on knowledge as a dominant source of competitive advantage. To survive selection pressures, firms need to recognize new external knowledge, assimilate it, and apply it to commercial ends. This ability, referred to as absorptive capacity (Cohen and Levinthal, 1990), has emerged as an underlying theme in strategy and organization research. Recent research has focused on the role of absorptive capacity in innovation (Tsai, 2001), business performance (Lane, Salk, \& Lyles, 2001; Tsai, 2001), intra-organizational transfer of knowledge (Gupta \& Govindarajan, 2000;

Szulanski, 1996), and interorganizational learning (Lane \& Lubatkin, 1998; Lane et al., 2001).

Despite the growing interest in absorptive capacity, few have captured the richness and multidimensionality of the concept. Moreover, while most studies have focused on the competitive benefits of absorptive capacity, organizational antecedents have been largely ignored (Lane, Koka, \& Pathak, 2002). The lack of research regarding this link is surprising, especially since Cohen and Levinthal (1990) emphasized the importance of organizational mechanisms and suggested considering what aspects of absorptive capacity are distinctly organizational. Even when organizational antecedents have been considered (e.g. Lane et al., 2001; Van den Bosch, Volberda, \& De Boer, 1999), their relationships with different dimensions of absorptive capacity have not been tested empirically. Although the ability to absorb new external knowledge can generate significant benefits (Cockburn, Henderson, \& Stern, 2000; Zollo \& Winter, 2002), organizational antecedents may have differential effects on dimensions of absorptive capacity, and subsequently lead to different performance outcomes. Zahra and George (2002), for instance, distinguished between four dimensions of absorptive capacity that constitute potential and realized absorptive capacity. They argued that firms need to manage these dimensions of absorptive capacity successfully to obtain superior performance. Firms focusing on acquisition and assimilation of new external knowledge (i.e. potential absorptive capacity) are able to continually renew their knowledge stock, but may 
suffer from the costs of acquisition without gaining benefits from exploitation. Conversely, firms focusing on transformation and exploitation (i.e. realized absorptive capacity) may achieve short-term profits through exploitation, but may fall into a competence trap (Ahuja \& Lampert, 2001) and may not be able to respond to environmental changes. Examining differential effects of organizational antecedents on potential and realized absorptive capacity would not only clarify how absorptive capacity may be developed, but also reveal why firms have difficulties in managing dimensions of absorptive capacity successfully.

The objective of this study is to address this issue and to contribute to existing literatures in two ways. First, we advance research on absorptive capacity by extending and empirically validating the conceptual distinction between potential and realized absorptive capacity (Zahra $\&$ George, 2002). Potential absorptive capacity, which includes knowledge acquisition and assimilation, captures efforts expended in identifying and acquiring new external knowledge and in assimilating knowledge obtained from external sources (Zahra \& George, 2002: 189). Realized absorptive capacity, which includes knowledge transformation and exploitation, encompasses deriving new insights and consequences from the combination of existing and newly acquired knowledge, and incorporating transformed knowledge into operations (Zahra \& George, 2002: 190). To date, corresponding measures for dimensions that form potential and realized absorptive capacity are still lacking. This study differentiates between these dimensions and further clarifies the distinctness of potential and realized absorptive capacity.

Second, we contribute to research regarding the link between combinative capabilities and absorptive capacity (Kogut \& Zander, 1992; Teece, Pisano, \& Shuen, 1997; Van den Bosch et al., 1999). We conceptually identify and empirically examine how common features of combinative capabilities affect dimensions of absorptive capacity. Previous research has argued that common features of combinative capabilities involve organizational mechanisms that each influences absorptive capacity in specific ways (e.g. Eisenhardt \& Martin, 2000; 
Henderson \& Cockburn, 1994; Van den Bosch et al., 1999). No insights, however, have been gained into how organizational mechanisms differentially affect acquisition and assimilation (i.e. potential absorptive capacity), and transformation and exploitation (i.e. realized absorptive capacity) of new external knowledge. Hence, this study reveals how organizational antecedents matter and examines the linkage between specific organizational mechanisms as common features of combinative capabilities and dimensions of absorptive capacity.

As Cohen and Levinthal (1990: 131-132) argued, absorptive capacity not only resides in firms, but also in organizational units. In this paper, we focus on the unit level. In the next section, we present the theoretical overview and hypotheses. Based on previous literatures, we discern important organizational mechanisms and explain their relationships to potential and realized absorptive capacity. After describing our research method, we present empirical findings using data on 462 organizational units. We conclude with a discussion of the results, implications, and issues for further research.

\section{THEORETICAL OVERVIEW AND HYPOTHESES}

The ability of units to absorb new external knowledge depends on the level of prior related knowledge (Cohen \& Levinthal, 1990). However, mere exposure to related external knowledge is not sufficient to internalize it successfully (Pennings \& Harianto, 1992). In addition to prior knowledge resources (e.g. Verona, 1999), units need to develop organizational capabilities, defined as combinative capabilities (Kogut \& Zander, 1992), which enable them to synthesize and apply current and newly acquired external knowledge (Eisenhardt \& Martin, 2000; Kogut \& Zander, 1992). Combinative capabilities are path-dependent in their emergence and idiosyncratic in detail; however they exhibit common features (Eisenhardt \& Martin, 2000: 1116). These commonalities involve organizational mechanisms, such as cross-functional teams and participation in decision-making, which each provides specific ways of dealing with dimensions of absorptive capacity. Matusik (2002: 458), for instance, related formal and 
informal structures to firm capabilities and specifically highlights the importance of crossfunctional coordination mechanisms in creating a conducive knowledge context. Henderson and Cockburn (1994: 66-67) argued that in addition to cross-functional boundary-spanning mechanisms, architectural or combinative capabilities include control systems and dominant values that influence the ability to access new external knowledge and to integrate knowledge flexibly. Similarly, Verona (1999) suggested that capabilities aimed at absorbing external knowledge are strictly linked to managerial structures, systems, and social relations. However, relationships between these organizational mechanisms associated with combinative capabilities and dimensions of absorptive capacity are still unclear. We submit specific organizational mechanisms as common features of combinative capabilities and examine how they influence potential and realized absorptive capacity. To structure our analysis, we discuss three types of combinative capabilities: (1) coordination capabilities, (2) systems capabilities, and (3) socialization capabilities (cf. Van den Bosch et al., 1999: 556).

\section{Organizational Mechanisms Associated with Coordination Capabilities}

Coordination capabilities enhance knowledge exchange across disciplinary and hierarchical boundaries (Henderson \& Cockburn, 1994; Matusik, 2002; Teece et al., 1997). Common features of coordination capabilities are cross-functional interfaces, participation in decisionmaking, and job rotation (Galbraith, 1973; Henderson \& Cockburn, 1994; Van den Bosch et al., 1999). These organizational mechanisms bring together different sources of expertise and increase lateral interaction between functional or 'component' knowledge.

Units use cross-functional interfaces such as liaison personnel, task forces, and teams to enable knowledge exchange (Gupta \& Govindarajan, 2000). Cross-functional interfaces result in lateral forms of communication that deepen knowledge flows across functional boundaries and lines of authority. They promote non-routine and reciprocal information processing (Egelhoff, 1991) and contribute to a unit's ability to overcome differences, interpret issues, and 
build understanding about new external knowledge (Daft \& Lengel, 1986). Thus, crossfunctional interfaces enhance knowledge acquisition and assimilation underlying a unit's potential absorptive capacity.

Hypothesis 1a. Cross-functional interfaces will be positively related to acquisition and assimilation of new external knowledge (i.e. potential absorptive capacity)

In addition, cross-functional interfaces are beneficial to integrating diverse knowledge components and creating a desirable amount of redundancy within units (Cohen \& Levinthal, 1990: 134; Daft \& Lengel, 1986). They support unit members in rethinking the systematic nature of existing products and services and revisit the ways in which components are integrated together (Henderson \& Cockburn, 1994). Accordingly, cross-functional interfaces enable employees to combine sets of existing and newly acquired knowledge. Moreover, crossfunctional interfaces provide an effective way of generating commitment and facilitating the implementation of decisions (Bahrami \& Evans, 1987). Thus, cross-functional interfaces increase transformation and exploitation, which underlie a unit's realized absorptive capacity. Hypothesis 1b. Cross-functional interfaces will be positively related to transformation and exploitation of new external knowledge (i.e. realized absorptive capacity)

Participation in decision-making indicates the extent to which subordinates take part in higher-level decision making processes (Hage \& Aiken, 1967). Participation increases the range of prospective 'receptors' to the environment (Cohen \& Levinthal, 1990). These receptors selectively act on new external knowledge and serve as both filter and facilitator of new external knowledge acquisition (Aldrich \& Herker, 1977). In addition, participation allows for the interplay between a variety of perspectives and leads to a rich internal network of diverse knowledge (Hage \& Aiken, 1967: 510) that supports assimilation of new external 
knowledge. Thus, exposure to external knowledge sources through 'receptors' and the interplay between diverse knowledge structures enable knowledge acquisition and assimilation and increase a unit's potential absorptive capacity.

Hypothesis 2a. Participation in decision-making will be positively related to acquisition and assimilation of new external knowledge (i.e. potential absorptive capacity)

Although conceptual research has suggested that participation in decision-making increases the quantity and quality of ideas or proposals (e.g. Pierce \& Delbecq, 1977; Sheremata, 2000), it may slow down transformation and exploitation of new external knowledge considerably. Zaltman, Duncan, and Holbek (1973), for instance, argued that participation facilitates the initiation stage of innovative behavior, but hinders the implementation stage. Because of the difficulty of gaining consensus, research has indeed found a negative effect of participation on new product development speed (Atuahene-Gima, 2003). Moreover, Lin and Germain (2003) revealed that decentralization was inversely related to customer product knowledge utilization. These empirical results suggest that participation in decision-making hampers informationprocessing efficiency (Cardinal, 2001) and may decrease a unit's realized absorptive capacity.

Hypothesis $2 b$. Participation in decision-making will be negatively related to transformation and exploitation of new external knowledge (i.e. realized absorptive capacity)

Job rotation is the lateral transfer of employees between jobs (Campion, Cheraskin, \& Stevens, 1994). Job rotation has been assumed to enhance redundancy as well as diversity of backgrounds, to increase problem-solving skills, and to develop organizational contacts (Cohen \& Levinthal, 1990; Noe \& Ford, 1992). Diverse knowledge structures support explorative learning (McGrath, 2001) and increase the prospect that new external knowledge is related to existing knowledge. Rotation of employees who each possesses diverse and varied knowledge 
also augments a unit's capacity for making novel linkages and associations (Cohen \& Levinthal, 1990). Job rotation therefore enables acquisition and assimilation of new external knowledge that constitute potential absorptive capacity.

Hypothesis 3 a. Job rotation will be positively related to acquisition and assimilation of new external knowledge (i.e. potential absorptive capacity)

In addition, job rotation enhances the awareness of employees' knowledge and skills in other functional areas within the unit (Campion et al., 1994). Such awareness about where complementary expertise may reside increases the ability of employees to identify opportunities for transformation and exploitation of new external knowledge (Cohen \& Levinthal, 1990: 133; Matusik \& Hill, 1998). Moreover, job rotation develops organizational contacts that help with building a coalition needed for successful exploitation of new external knowledge (Mumford, 2000). Job rotation thus also increases transformation and exploitation of new external knowledge underlying a unit's realized absorptive capacity.

Hypothesis $3 b$. Job rotation will be positively related to transformation and exploitation of new external knowledge (i.e. realized absorptive capacity)

\section{Organizational Mechanisms Associated with Systems Capabilities}

Systems capabilities program behaviors in advance of their execution and provide a memory for handling routine situations (Galbraith, 1973; March \& Simon, 1958; Van den Bosch et al., 1999). They typically exhibit common features, i.e. formalization and routinization, which establish patterns of organizational action (Cohen and Bacdayan, 1994: 555; Galunic \& Rodan, 1998).

Formalization is the degree to which rules, procedures, instructions, and communications are formalized or written down (Khandwalla, 1977). The reliance on rules and procedures 
reduces the likelihood that individuals deviate from established behavior (Weick, 1979). Formalization acts as a frame of reference that constrains exploration efforts and directs attention toward restricted aspects of the external environment (Weick, 1979). In this sense, formalization tends to limit the intensity and scope of efforts expended in knowledge acquisition. Moreover, formalization also inhibits rich, reciprocal knowledge interaction and hinders individuals in assimilating new external knowledge. Accordingly, formalization negatively influences acquisition and assimilation of new external knowledge underlying potential absorptive capacity.

Hypothesis 4a. Formalization will be negatively related to acquisition and assimilation of new external knowledge (i.e. potential absorptive capacity)

Organizational units use formalization to respond to organizational phenomena in a known way (Daft \& Lengel, 1986). Formalization supports the retrieval of knowledge that has already been internalized (Lyles \& Schwenk, 1992) and enhances the causal understanding of sets of tasks within units. Accordingly, formalization increases the likelihood that unit members will identify opportunities for transformation of new external knowledge (Galunic \& Rodan, 1998; Zollo \& Winter, 2002: 342). Through formalization, units also codify best practices so as to make knowledge more efficient to exploit, easier to apply, and to accelerate its implementation (Lin \& Germain, 2003; Zander \& Kogut, 1995). Formalization, thus, enhances transformation and exploitation of new external knowledge underlying realized absorptive capacity.

Hypothesis $4 b$. Formalization will be positively related to transformation and exploitation of new external knowledge (i.e. realized absorptive capacity)

Units pursue routinization to develop a sequence of tasks that require relatively little attention (Galunic \& Rodan, 1998) and to ensure that inputs are transformed into outputs 
(Perrow, 1967). Routine tasks are invariable, repetitious, and handle lower frequencies of unexpected and novel events (Hage \& Aiken, 1969; Perrow, 1967; Withey, Daft, \& Cooper, 1983). Employees that execute routine tasks only deal with a few exceptions and a narrow range of problems (Perrow, 1967; Volberda, 1996). Routinization therefore limits the search for new external knowledge and leads to a narrow scope of information processing. Moreover, it also restricts interaction among unit members (Daft \& Macintosh, 1981; Galbraith, 1973) and decreases the range of unit members interpreting new external knowledge. Thus, routinization of organizational behavior decreases a unit's ability to acquire and assimilate new external knowledge underlying potential absorptive capacity.

Hypothesis 5a. Routinization will be negatively related to acquisition and assimilation of new external knowledge (i.e. potential absorptive capacity)

Routine tasks establish automatic patterns of behavior and increase understanding of task relationships. As unit members preplan the handling of their tasks (Daft \& Macintosh, 1981), routinization provides efficient structures for collective action and decreases efforts spent on decision-making and implementation (Cohen \& Bacdayan, 1994). In this sense, units that routinize organizational behavior are able to efficiently transform new external knowledge into existing sets of tasks (Cohen \& Bacdayan, 1994). Additionally, as routine tasks are wellpracticed and predictable, they permit closely coordinated exploitation of knowledge in pursuing collective objectives (Adler, Goldoftas, \& Levine, 1999; Gersick \& Hackman, 1990; Grant, 1996). Accordingly, routinization enables a unit's realized absorptive capacity. Hypothesis 5b. Routinization will be positively related to transformation and exploitation of new external knowledge (i.e. realized absorptive capacity)

\section{Organizational Mechanisms Associated with Socialization Capabilities}


Socialization capabilities create broad, tacitly understood rules for appropriate action (Camerer \& Vepsalainen, 1988; Volberda, 1998). They contribute to common codes of communication and dominant values (Henderson \& Cockburn, 1994; Teece et al., 1997; Verona, 1999) and exhibit two commonalities: connectedness and socialization tactics (Adler \& Kwon, 2002; Nahapiet \& Ghoshal, 1998). These organizational mechanisms refer to two aspects of social relations: the structural aspect or density of linkages and cognitive aspect or shared social experiences.

The density of linkages, or connectedness, serves as a governance mechanism and facilitates knowledge exchange (Jaworski \& Kohli, 1993; Rowley, Behrens, \& Krackhardt, 2000). Dense networks are advantageous for developing trust and cooperation, but increase the redundancy of information and diminish access to divergent perspectives (Nahapiet \& Ghoshal, 1998; Sethi, Smith, \& Park, 2001). Accordingly, dense networks constrain unit members to perform broad searches for a variety of external knowledge sources. They "limit the openness to information and to alternative ways of doing things, producing collective blindness" (Nahapiet \& Ghoshal, 1998: 245). Therefore, connectedness inhibits the acquisition and assimilation of new external knowledge (i.e. potential absorptive capacity).

Hypothesis 6a. Connectedness will be negatively related to acquisition and assimilation of new external knowledge (i.e. potential absorptive capacity)

Connectedness develops trust and cooperation and fosters the commonality of knowledge (Rowley et al., 2000). It encourages communication and improves the efficiency of knowledge exchange throughout units (Galunic \& Rodan, 1998). In this way, connectedness allows units to transform and exploit new external knowledge (Zahra \& George, 2002: 194). Moreover, connectedness reduces the likelihood of conflict regarding goals and implementation 
(Rindfleisch \& Moorman, 2001). Thus, connectedness facilitates the transformation and exploitation of newly acquired knowledge and develops a unit's realized absorptive capacity.

Hypothesis 6b. Connectedness will be positively related to transformation and exploitation of new external knowledge (i.e. realized absorptive capacity)

Organizational units use socialization tactics to structure shared socialization experiences (Ashforth \& Saks, 1996). Socialization tactics offer newcomers specific information and encourage them to interpret and respond to situations in a predictable way (Jones, 1986). They lead to custodial role orientations and the acceptance of the status quo because organizational members seek a high level of concurrence and conformance (Ashforth \& Saks, 1996; Jones, 1986). Socialization tactics increase the commitment of unit members to past policies and procedures (Randall, 1987). They can create mental prisons and lead to poor information search as well as selective perception of information and alternatives (Janis, 1982). Thus, socialization tactics hamper the ability to tap into new external knowledge sources (Cohen \& Levinthal, 1990) and impede a unit's ability to acquire and assimilate new external knowledge.

Hypothesis 7a. Socialization tactics will be negatively related to acquisition and assimilation of new external knowledge (i.e. potential absorptive capacity)

Socialization tactics affect the establishment of interpersonal relationships and lead to the congruence of values, needs, and beliefs among individuals within units (Ashforth \& Saks, 1996; Feldman, 1981; Van Maanen \& Schein, 1979). They teach newcomers a unit-specific language that facilitates the comprehension of background knowledge and communication with others (Chao et al., 1994; Fisher, 1986). In this way, socialization tactics enhance the combination of newly acquired and existing knowledge through facilitating bisociation among unit members (Zahra \& George, 2002). Moreover, socialization tactics lead to strong social 
norms and beliefs, which enhance commitment and compliance with exploitation processes of new external knowledge (Adler \& Kwon, 2002). Thus, socialization tactics enhance transformation and exploitation of new external knowledge.

Hypothesis $7 b$. Socialization tactics will be positively related to transformation and exploitation of new external knowledge (i.e. realized absorptive capacity)

\section{Setting and Data Collection}

\section{METHOD}

The empirical research was conducted at a large European multi-unit financial services firm. The firm has total assets of more than $\$ 350$ billion and ranks within the top 30 on the Fortune Global 500 in terms of total revenue in the banking industry. It is a broad-based financial service provider having branches in various countries that are geographically distinct entities with their own clientele. The products and services of the branches cover asset management, insurance, leasing, equity participation, corporate banking, and investment banking. In 2002, we administered a survey to general managers of 769 organizational units within 220 branches in one country. To ensure confidentiality, we agreed not to reveal the manager's name and asked to return the questionnaire directly to the research team. A total of 462 questionnaires were returned, corresponding with a response rate of 60.1 percent. The respondents had a mean company tenure of 7.7 years $($ s.d. $=8.14)$. The average size of the organizational units was 32.79 (s.d. = 21.09) full-time employees.

To test for nonresponse bias, we examined differences between respondents and nonrespondents. A t-test showed no significant differences $(\mathrm{p}<.05)$ between the two groups based on the number of full-time employees of units and branches, total assets of branches, and units' prior performance. We also compared the early and late respondents in terms of demographic characteristics and model variables. These comparisons did not reveal any significant differences $(\mathrm{p}<.05)$, indicating that differences between respondents were not related to nonresponse bias. To examine reliability issues associated with single-informant 
data, we surveyed two additional members of each responding unit. Both management team members and senior employees responsible for coordinating units were asked to participate. This follow-up survey resulted in 96 responses from 71 units that were comparable in size, age, and prior performance to our full sample. We calculated an interrater agreement score $\left(\mathrm{r}_{\mathrm{wg}}\right)$ for each study variable (James, Demaree, \& Wolf, 1993). The median interrater agreement ranged from .68 to .93 , suggesting adequate agreement. In addition, examination of intra-class correlations revealed a strong level of interrater reliability: correlations were consistently significant at the .001 levels (Jones, Johnson, Butler, \& Main, 1983). We also performed Harman's one-factor test on items included in our regression model to examine whether common method bias may have augmented relationships. Because we found multiple factors, and the first factor did not account for the majority of the variance, we were less concerned about potential problems associated with common method bias (Podsakoff \& Organ, 1986).

\section{Measurement and Validation of Constructs}

This study mainly used existing scales from literature. However, appropriate scales for potential absorptive capacity, realized absorptive capacity, and job rotation were not available. The following steps were taken to develop new measures for these constructs. First of all, we reviewed relevant literature and generated a pool of items to tap the domain of each construct. From this pool of items, unique items were selected for inclusion in initial scales. Next, we conducted in-depth interviews with 15 unit managers at different branches. The managers were asked to complete the questionnaire and indicate any ambiguity regarding the phrasing of the items. During follow-up interviews, they were invited to suggest improvements to the questionnaire. Subsequently, the phrasing of items was further enhanced by the authors and peers and resulted in a final version of the questionnaire.

Potential and realized absorptive capacity. To examine potential and realized absorptive capacity, we sought to measure the dimensions that have been defined (Zahra \& George, 
2002). Items were measured on a seven-point disagree/agree scale and were partially based on existing items in the literature regarding absorptive capacity (Szulanski, 1996) and market orientation (Jaworski \& Kohli, 1993). The appendix presents the items of potential and realized absorptive capacity we used in our study. Potential absorptive capacity consists of acquisition and assimilation of new external knowledge. Six items assessed the intensity and direction of efforts expended in knowledge acquisition. In addition, three items measured assimilation and gauged the extent to which units were able to analyze and understand new external knowledge. The scales for acquisition and assimilation were reliable (reliabilities: acquisition, .79; assimilation, .76). Realized absorptive capacity includes transformation and exploitation of new external knowledge. Six items measured transformation and assessed the extent to which units were able to facilitate recognizing opportunities and consequences of new external knowledge for existing operations, structures, and strategies (Zahra \& George, 2002). Six items tapped into the extent to which units were able to exploit new external knowledge. The scale gauged the ability of units to incorporate new external knowledge into their operations. Both scales were reliable (reliabilities: transformation, .72; exploitation, .71).

We conducted confirmatory factor analysis (CFA) of the items pertaining to dimensions of potential and realized absorptive capacity in order to check for construct independence. Each item was allowed to load only on the factor for which it was a proposed indicator. Results indicate that a four-factor model fits the data moderately well $\left(\chi^{2} / \mathrm{df}=2.76\right.$, goodness-of-fit index $[\mathrm{GFI}]=.91$, comparative fit index $[\mathrm{CFI}]=.90$, root-mean-square error of approximation $[$ RMSEA $]=.06)$. Item loadings were as proposed and were significant $(\mathrm{p}<.001)$, providing evidence for convergent validity. The hypothesis that the four underlying dimensions of absorptive capacity converged on one common factor was unambiguously rejected $\left(\Delta \chi^{2}{ }_{6}=\right.$ 1097.00, $\mathrm{p}<.001)$. Our four-factor model also provided a better fit to the data than its plausible rival two-factor model. All the fit indexes of the two-factor model were worse than those of our 
four-factor model. In addition, a chi-square difference test showed that the fit of the threefactor model was significantly worse than our four-factor model $\left(\Delta \chi^{2}{ }_{5}=840.03, \mathrm{p}<.001\right)$. Accordingly, the four dimensions underlying potential and realized absorptive capacity are not only theoretically, but also empirically distinguishable.

To further assess the construct validity of the measures for potential and realized absorptive capacity, we compared the scores of the study variables with a separate overall measure of absorptive capacity (Szulanski, 1996). Using a nine-item scale $(\alpha=.90)$, respondents described their unit's ability to absorb new external knowledge regarding a new knowledge-intensive financial service, i.e. employee benefits, that had been released six months before the initial questionnaire. Correlations between the study variables and the overall measure of absorptive capacity regarding the new financial service were positive and significant (acquisition, $r=.44$, $\mathrm{p}<.001$; assimilation, $\mathrm{r}=.37, \mathrm{p}<.001$; transformation, $\mathrm{r}=.34, \mathrm{p}<.001$; exploitation, $\mathrm{r}=.24$, $\mathrm{p}<.001$ ), suggesting evidence for convergence validity. In addition, we collected archival data through internal corporate records on the average number of services regarding employee benefits purchased by clients. Correlations between the study variables and this service performance measure were also positive and significant (acquisition, $r=.23, p<.001$; assimilation, $\mathrm{r}=.13, \mathrm{p}<.01$; transformation, $\mathrm{r}=.22, \mathrm{p}<.001$; exploitation, $\mathrm{r}=.14, \mathrm{p}<.01$ ), suggesting that organizational units with higher levels of potential and realized absorptive capacities obtained higher levels of service performance regarding the new financial service.

Organizational mechanisms associated with combinative capabilities. To measure crossfunctional interfaces, we asked managers to indicate the extent to which their unit used liaison personnel, temporary task forces, and permanent teams to coordinate activities (Galbraith, 1973). The final measure was a weighted average of the three items (cf. Gupta \& Govindarajan, 2000), ranging from 1 for liaison personnel to 3 for permanent teams (mean = 
4.39; s.d. = 1.18). We used the construct of participation in decision-making (Dewar, Whetten, $\&$ Boje, 1980; Hage \& Aiken, 1967$)$ to measure participation $(\alpha=.79)$. Job rotation was measured with two items that tapped into the extent to which employees were rotated between different functions within and between subunits $(\alpha=.77)$. The items were as follows "employees in our unit are regularly rotated between different functions" and "employees are regularly rotated between different subunits". To measure formalization, we used a five-item formalization scale $(\alpha=.73)$ from Desphandé and Zaltman (1982). Routinization tapped into the extent to which tasks within units were invariable, uniform or predictable (Whitney, Daft, \& Cooper, 1983). Based on Perrow's (1967) work on unit technology, routinization $(\alpha=.73)$ was measured by the exceptions scale of Whitney, Daft, and Cooper (1983). Connectedness ( $\alpha$ $=.74$ ) was measured with a four-item scale (Jaworski \& Kohli, 1993). Connectedness measured the extent to which individuals in organizational units were networked to various levels of the hierarchy. We used two categorizations of Van Maanen and Schein's model (1979: 232) to measure socialization tactics: collective versus individual and serial versus disjunctive tactics (cf. Jones, 1986). Previous research suggested that these two categorizations affect custodial role orientations, the congruence of values and beliefs, and newcomer adjustment to organizations (Ashforth \& Saks, 1996; Grant \& Bush, 1996). Since we were interested in the overall effect of socialization tactics, we constructed a measure for socialization tactics by averaging the scores of collective socialization tactics $(\alpha=.74)$ and serial socialization tactics $(\alpha=.76)$.

An integrated CFA on all items of potential and realized absorptive capacity, and organizational mechanisms associated with combinative capabilities (with each item constrained to load only on the factor for which it was the proposed indicator) yielded a model that fits the data moderately well $\left(\chi^{2} / \mathrm{df}=2.40\right.$, goodness-of-fit index $[\mathrm{GFI}]=.90$ comparative fit index $[\mathrm{CFI}]=.90$, root-mean-square error of approximation $[\mathrm{RMSEA}]=.055)$. Item 
loadings were as proposed and significant $(\mathrm{p}<.01)$. The scale for cross-functional interfaces was not subjected to confirmatory factor analysis due to the weighted structure.

Control variables. As larger units may have more resources, yet may lack the flexibility to acquire and assimilate new external knowledge, we included the natural logarithm of the number of full-time employees within units to account for unit size. In accordance with the reasoning to include unit size, we included branch size as well. Branch size (average: 136.36 full-time employees) was calculated by the natural logarithm of the number of full-time employees within a branch. A unit's age, measured by the number of years from its founding, was included since age may influence knowledge acquisition and exploitation (Autio, Sapienza, \& Almeida, 2000). To control for the effect that units may specialize in different markets and have different ranges of products and services, we included unit client focus that indicates whether the unit provided products and services for private clients (coded as 0 ) or for business clients (coded as 1). Units with a strong history of high performance are more likely to invest in absorptive capacity. Hence, we included a unit's past performance. Because units may have different strategic priorities, we adjusted performance data to evaluate each unit. Following Tsai (2001), we used a unit's profitability-achieved rate, a unit's profitability divided by its target profitability. We also controlled for branch's past performance and included a branch's profitability-achieved rate, a branch's return on investment divided by its target return. The performance measures, as well as the achieved rates for the units and branches in this study, were collected for the time period 1999-2001 through internal corporate records. Environmental aspects may trigger units to develop their potential or realized absorptive capacity. Accordingly, we included a dummy variable, urban/rural unit location (0 $=$ rural location; 1 = urban location) to account for different business dynamics such as market concentration and competitiveness (Dietz, Pugh \& Wiley, 2004). The urban/rural classification was collected through internal corporate records. Environmental dynamism can trigger a unit to 
develop potential absorptive capacity (Zahra \& George, 2002). We therefore included a threeitem scale $(\alpha=.75)$ that captures environmental dynamism (Dill, 1958; Volberda \& Van Bruggen, 1997). Sample items are "our clients regularly ask for complete new products and services" and "in our market, changes are taking place continuously".

\section{ANALYSIS AND RESULTS}

Table 1 presents descriptive statistics and correlations for the study variables. To examine the issue of multicollinearity, we calculated variance inflation factors (VIF) in each of the regression equations. The maximum VIF within the models was 1.44 , which is well below the rule-of-thumb cut-off of 10 (Neter, Wasserman, \& Kutner, 1990).

\section{Insert Table 1 about here}

Table 2 presents the results of the hierarchical regression analyses for organizational mechanisms and both components of absorptive capacity. Unstandardized coefficients with standard errors in parantheses as well as standardized coefficients in the adjacent column are reported. Models 1 and 2 relate to potential absorptive capacity. As expected, organizational mechanisms associated with coordination capabilities have positive and significant effects on potential absorptive capacity. In particular, coefficients indicate that cross-functional interfaces (acquisition: $\mathrm{p}<.01$; assimilation: $\mathrm{p}<.01$ ) and job rotation (acquisition: $\mathrm{p}<.01$; assimilation: $\mathrm{p}<.05$ ) enhance a unit's potential absorptive capacity, consistent with hypotheses 1a and 3a. Regarding hypothesis $2 \mathrm{a}$ we found mixed results. Participation in decision-making is positively associated with acquisition $(\mathrm{p}<.001)$, but not with assimilation $(\mathrm{p}>.10)$. Thus, participation in decision-making only triggers unit members to acquire new external knowledge. The coefficients for formalization (acquisition: $\mathrm{p}>.10$; assimilation: $\mathrm{p}>.10$ ) are not significant. Hypothesis 4a is not supported. Routinization of tasks (acquisition: $p<.001$; assimilation: $\mathrm{p}<.05$ ) has significant and negative effects on acquisition and assimilation of new 
external knowledge, supporting hypothesis 5a. Accordingly, the negative effect of organizational mechanisms associated with systems capabilities on potential absorptive capacity mainly originates from routinization of tasks. Hypothesis $6 a$ that posits a negative influence of connectedness on a unit's potential absorptive capacity is not supported. Results show that connectedness does not affect acquisition ( $\mathrm{p}>.10)$, and even positively influences assimilation $(\mathrm{p}<.01)$. Thus, contrary to our prediction, connectedness even enhances the assimilation of new external knowledge. Hypothesis 7a, which claims a negative relationship between socialization tactics and potential absorptive capacity, is also not supported. The coefficients (acquisition: $\mathrm{p}>.10$; assimilation: $\mathrm{p}>.10$ ) are not significant. Thus, connectedness and socialization tactics do not disrupt acquisition and assimilation of new external knowledge.

Insert Table 2 about here

Models 3 and 4 in Table 2 present the results of the hierarchical regression analysis for organizational antecedents and realized absorptive capacity. The coefficients for crossfunctional interfaces (transformation: $\mathrm{p}<.05$; exploitation: $\mathrm{p}>.10$ ) and job rotation (transformation: $\mathrm{p}<.05$; exploitation: $\mathrm{p}>.10$ ) are positive and significant for transformation; however, they are not significant for exploitation. Hypotheses $1 \mathrm{~b}$ and $3 \mathrm{~b}$ receive only support in model 3; that is, they are supported for transformation of new external knowledge. Crossfunctional interfaces and job rotation do not increase exploitation of knowledge underlying realized absorptive capacity. Participation in decision-making (transformation: $\mathrm{p}<.05$; exploitation: $\mathrm{p}>.10$ ) has no significant negative effect on realized absorptive capacity. Contrary to our prediction, participation in decision-making even increases transformation of new external knowledge. Hypothesis $2 \mathrm{~b}$ is not supported. As hypothesized, formalization (transformation: $\mathrm{p}<.05$; exploitation: $\mathrm{p}<.001$ ) positively influences a unit's realized absorptive capacity. Hypothesis $4 \mathrm{~b}$ is supported. The coefficients for routinization (transformation: $\mathrm{p}<.01$; 
exploitation: $\mathrm{p}>.10$ ) are both negative and only significant for transformation. Hypothesis $5 \mathrm{~b}$, positing a positive relationship between routinization and realized absorptive capacity, is not supported. Coefficients for connectedness (transformation: $\mathrm{p}<.001$; exploitation: $\mathrm{p}<.001$ ) and socialization tactics (transformation: $\mathrm{p}<.001$; exploitation: $\mathrm{p}<.001$ ) are positive and highly significant. In accordance with hypotheses $6 \mathrm{~b}$ and $7 \mathrm{~b}$, connectedness and socialization tactics increase a unit's realized absorptive capacity ${ }^{1}$.

\section{Comparison of Relative Effects}

To gain further insights into the relative effects of organizational antecedents on potential and realized absorptive capacity, we determined the relative importance of each set of organizational mechanisms (i.e. associated with each type of combinative capability) over another, by performing F-tests involving both the full and restricted models (c.f. Hansen \& Wernerfelt, 1989; Kota \& Nair, 1995). Results suggested several important issues. First, acquisition of new external knowledge is most strongly affected by organizational mechanisms associated with coordination capabilities; organizational mechanisms associated with socialization capabilities have little or no impact. Second, organizational mechanisms associated with coordination and socialization capabilities primarily explain assimilation of new external knowledge. Interestingly, organizational mechanisms associated with socialization capabilities have the strongest effect. Third, the effects of organizational mechanisms associated with socialization capabilities on transformation and exploitation (i.e. realized absorptive capacity) are stronger than organizational mechanisms associated with either coordination capabilities or systems capabilities. Connectedness and socialization tactics, for instance, account for more than three times as much variance of transformation as crossfunctional interfaces, participation in decision-making, and job-rotation.

\footnotetext{
${ }^{1}$ We ran additional regression analyses to examine curvilinear relationships. Results revealed an inverted Ushaped relationship between cross-functional interfaces and transformation. Thus, although cross-functional interfaces contribute to transformation, using many liaison persons, task forces, and cross-functional teams may eventually hurt transformation because of creating too much redundancy among unit members.
} 


\section{DISCUSSION AND CONCLUSION}

The objective of this study was to explore the differential effects of organizational antecedents on a unit's potential and realized absorptive capacity. Although research has been devoted to outcomes of absorptive capacity, organizational antecedents of absorptive capacity have been largely ignored. In addition, research into absorptive capacity has only begun to explore components and dimensions. This empirical study assesses potential and realized absorptive capacity and examines the linkage between specific organizational mechanisms as common features of combinative capabilities and dimensions of absorptive capacity.

\section{Implications}

Our study contributes to literatures on absorptive capacity and combinative capabilities in several ways. Most importantly, our results reveal that organizational mechanisms associated with combinative capabilities differentially drive a unit's potential and realized absorptive capacity. The present study contributes to our understanding as to why certain units are able to acquire and assimilate new external knowledge, but are not able to transform and exploit it successfully. Overall, our research indicates that organizational mechanisms associated with coordination capabilities (i.e. cross-functional interfaces, participation, and job-rotation) primarily enhance potential absorptive capacity while organizational mechanisms associated with socialization capabilities (connectedness and socialization tactics) primarily strengthen realized absorptive capacity. These results reveal that organizational units may differ in their ability to manage levels of potential and realized absorptive capacity, follow different developmental paths, and differ in their ability to create value from their absorptive capacity.

Our findings indicate that organizational mechanisms associated with coordination capabilities enhance a unit's potential absorptive capacity. Participation in decision-making, however, only increases acquisition of new external knowledge; it does not enhance assimilation of newly acquired knowledge. A possible explanation for this result is that 
participation in decision-making does not necessarily result in collective assimilation efforts, but rather leads to lower-level assimilation of new external knowledge by narrowly focused unit members. Future studies may incorporate different levels of analyses to investigate the unanticipated effect of participation in decision-making on assimilation of new external knowledge. Although cross-functional interfaces, participation in decision-making, and job rotation have relatively little impact, they also enhance a unit's realized absorptive capacity. However, these organizational mechanisms only increase transformation of new external knowledge; they are not related to exploitation. These results suggest that, in contrast to transformation, exploitation requires more stable and densely connected knowledge structures. The temporal nature of cross-functional interfaces and job-rotation indeed fosters acquisition, assimilation, and transformation of new external knowledge, but may be insufficient to embed new external knowledge into systems and structures (Matusik \& Hill, 1998). Moreover, results indicate that participation does not negatively influence transformation as predicted, but rather positively influences transformation through initiating new ideas, insights, and opportunities.

Organizational mechanisms associated with systems capabilities provide somewhat surprising results. Firstly, although formalization contributes to a unit's realized absorptive capacity as we predicted, it does not decrease a unit's potential absorptive capacity. One main reason could be that acquisition and assimilation may be formalized to some extent. Welldesigned rules and procedures capture prior experiences that may enable employees to search for, and assimilate, new external knowledge (Adler \& Borys, 1996). Secondly, our study confirms that routinization negatively influences a unit's potential absorptive capacity. However, contrary to our prediction, it also shows that routinization negatively influences transformation underlying a unit's realized absorptive capacity. Although it has been suggested that routinization enhances efficient integration of existing knowledge (cf. Grant, 1996; Gersick \& Hackman, 1990), our study reveals that it impedes the flexible incorporation of 
newly acquired and existing knowledge (Volberda, 1996). These two contradicting results regarding systems capabilities highlight the benefits of codifying established behavior over holding it tacit (Zollo \& Winter, 2002). In contrast to making established behavior tacit through routinization, codification efforts through formalization enhance a unit's ability to transform and exploit new external knowledge, and to initiate recombinations necessary for developing new competences and capabilities (Galunic \& Rodan, 1998; Zollo \& Winter, 2002). Routinization seems to separate knowledge, to constrain joint learning, and to restrict the creation of new knowledge by imposing existing knowledge (Dougherty, 1992).

Our findings reveal the relative importance of organizational mechanisms associated with socialization capabilities in enhancing realized absorptive capacity. Interestingly, we found a strong and positive effect of connectedness on potential absorptive capacity, or in particular, the assimilation of new external knowledge. To some degree this pattern bears similarities to recent studies that suggest that low connectedness increases the overall access to diverse knowledge sources, yet may not be sufficient in supporting a regular and reliable flow of knowledge (e.g. Hansen, 1999). A dense network within units may motivate employees to be of assistance to each other, and allow two-way interaction that helps the interpretation and understanding of new external knowledge (Cohen \& Levinthal, 1990; Morrison, 2002). Our study suggests that in addition to establishing ties with external sources of new knowledge (Hansen, 1999; Tsai, 2001), units require dense networks of ties within units to assimilate, transform, and exploit new external knowledge. Moreover, findings indicate that socialization tactics do not disrupt acquisition and assimilation of new external knowledge. Although previous studies have suggested that socialization tactics result into custodial role orientations and well-established norms and beliefs, future research may explore the intent of these tactics and investigate to what extent certain socialization tactics contribute to an orientation towards openness. 
The present study advances our understanding of combinative capabilities through conceptually identifying and empirically examining common features of coordination, systems, and socialization capabilities. Although effective combinative capabilities for absorbing new external knowledge exhibit common features, it does not imply that a particular type of combinative capability is identical across units (Eisenhardt \& Martin, 2000). Our findings reveal, for instance, that cross-functional interfaces, such as liaison devices and crossfunctional teams, positively influence acquisition and assimilation of new external knowledge. However, the composition of a cross-functional team or location of liaison devices may be idiosyncratic to units. Moreover, formalization strongly increases the level of a unit's realized absorptive capacity. However, units may use various rules and procedures that differ in design and content, thereby executing formalization differently and developing an idiosyncratic systems capability. Thus, effective coordination, systems, and socialization capabilities may differ in details as long as important commonalities as identified and examined in our study are present (Eisenhardt \& Martin, 2000: 1110).

From a strategic management perspective, our study assumes that performance differences may arise when units vary in developing effective combinative capabilities and pursue different developmental paths of potential and realized absorptive capacity. Previous research has suggested that market dynamism moderates the effectiveness of both components of absorptive capacity (Eisenhardt \& Martin, 2000; Zahra \& George, 2002). To gain preliminary insights into these strategic implications, we collected performance data through internal corporate records, and included four interaction terms, i.e. acquisition and dynamism, assimilation and dynamism, transformation and dynamism, and exploitation and dynamism. Using a unit's financial performance as dependent variable, with all control variables included, we found that units with well-developed potential absorptive capacity $\left(\beta_{\text {acquisition*dynamism }}=.10\right.$, $\left.\mathrm{p}<.01 ; \beta_{\text {assimilation*dynamism }}=.11, \mathrm{p}<.01\right)$ improve their performance in dynamic environments. 
Interestingly, coefficients for realized absorptive capacity and environmental dynamism were mixed $\left(\beta_{\text {transformation*dynamism }}=.08, \mathrm{p}<.10 ; \beta_{\text {exploitation*dynamism }}=-.12, \mathrm{p}<.01\right)$. Organizational units with well-developed realized absorptive capacity do not necessarily increase their performance in dynamic environments. Rather, exploitation even decreases performance in dynamic environments. Overall, these preliminary findings have two interesting implications. First, organizational units operating in dynamic markets improve their performance by increasing their potential absorptive capacity. Potential absorptive capacity provides organizational units with strategic advantages, such as greater flexibility in reconfiguring resources and effective timing of knowledge deployment at lower costs that are necessary to sustain a competitive advantage (Zahra \& George, 2002: 195-196). Second, organizational units may not always be better off by fully realizing their potential absorptive capacity in dynamic environments. Although realized absorptive capacity leads to an increasing rate of innovation, these products and services may rapidly converge to industry standards (Eisenhardt \& Martin, 2000; Zahra \& George, 2002) and become obsolete relative to current environmental demands (Sorensen \& Stuart, 2000). Accordingly, units operating in dynamic markets need to selectively act upon their potential absorptive capacity and only exploit certain aspects of newly acquired knowledge. These findings suggest managing levels of potential and realized absorptive capacity more timely as the logic for competitive advantage (Eisenhardt \& Martin, 2000).

\section{Limitations}

Several limitations of this study merit discussion. First, our data were self-reported assessments of unit managers. Although we took several steps both in the design and testing phases to limit concerns regarding single-informant data, the issues of key informant bias and common method bias cannot be totally ruled out. However, a strong interrater agreement and interrater reliability, together with the confidentiality that was assured for respondents reduced our concerns that respondents artificially inflated or disguised their responses. Additionally, 
Harman's one-factor analysis provided evidence against the presence of one common factor. Common method bias would also have produced consistent effects of the same variables on both components of absorptive capacity yet we found differential effects of several variables on potential and realized absorptive capacity. Second, although the results presented here confirm the majority of the hypotheses, the study is to some degree exploratory. New scales were developed for inherently difficult to measure constructs such as the dimensions of absorptive capacity. Although we conducted additional analyses to assess the validity of our measures, it would be useful to further enhance these measurements and develop more elaborate scales. Future studies may also try to measure dimensions of absorptive capacity using objective measures and relate these to our measures. Third, our survey research was conducted at multiple organizational units within branches of a large financial services firm. Such a focus helped to account for corporate-, industry- and country-specific differences that might have otherwise masked significant effects. Empirical studies in a wider variety of organizations within different industries are necessary to further generalize the findings. Fourth, the data employed in this study were cross-sectional. Although our results are consistent with the theoretical predictions, further longitudinal research should empirically establish the causal claim of our model.

\section{Directions for Future Research}

The present study provides several issues for future research. Future research may incorporate additional antecedents of potential and realized absorptive capacity such as organizational form (Van den Bosch et al., 1999), incentive systems, and dimensions of external linkages of organizational units. Future studies may also incorporate multiple levels of analysis and examine individual-level as well as organizational-level variables (Van den Bosch, Van Wijk, \& Volberda, 2003). Furthermore, investigating combined or moderating effects of organizational antecedents (Siggelkow, 2002) would further enhance our 
understanding of how organizational units manage levels of potential and realized absorptive capacity. Particular combinations of organizational mechanisms, for instance, may even enhance all dimensions of absorptive capacity. Accordingly, future research may investigate how such contextual ambidextrous units combine contradictory elements (cf. Gibson \& Birkinshaw, 2004) and increase both their levels of potential and realized absorptive capacities simultaneously.

To better understand the effectiveness of potential and realized absorptive capacity, future studies may investigate what kind of balance between potential and realized absorptive capacity leads to superior performance. With the moderating effects of environmental dynamism in mind, we would expect that units with a baseline level of realized absorptive capacity and a high level of potential absorptive capacity obtain above-normal performance in dynamic markets. It would be useful to include various consequences such as strategic flexibility, innovativeness, and first-mover advantages (Volberda, 1998; Zahra \& George, 2002) as well as environmental moderators such as competitiveness and market growth. Examining various consequences and moderating effects would enhance our understanding of how certain (relative) levels of potential and realized absorptive capacities may contribute to achieving and sustaining competitive advantages.

Future studies may also address the role of knowledge attributes. For instance, Subramaniam and Venkatraman (2001) found that a higher degree of tacitness of newly acquired knowledge requires richer information-processing mechanisms such as crossfunctional teams, higher frequencies of communication, and more experienced members.

In conclusion, studying potential and realized absorptive capacity offers intriguing insights for both researchers and practitioners. We acknowledge that absorptive capacity is a multifaceted construct and provide new insights regarding how units may develop important sources of sustainable competitive advantages. 


\section{REFERENCES}

Adler, P.S., \& Borys, B. 1996. Two Types of Bureaucracy: Enabling and Coercive. Administrative Science Quarterly, 41: 61-89

Adler, P.S., Goldoftas, B., \& Levine, D.I. 1999. Flexibility versus Efficiency? A Case Study of Model Changeovers in the Toyota Product System. Organization Science, 10: 43-68

Adler, P.S., \& Kwon, S. 2002. Social Capital: Prospects for a New Concept. Academy of Management Review, 27: 17-40

Ahuja, G., \& Lampert, C.M. 2001. Entrepreneurship in the Large Corporation: a Longitudinal Study of how Established Firms create Breakthrough Inventions. Strategic Management Journal, 22: 521- 543

Aldrich, H., \& Herker, D. 1977. Boundary Spanning Roles and Organization Structure. Academy of Management Review, 2: 217-230

Ashforth, B.E., \& Saks, A.M. 1996. Socialization Tactics: Longitudinal Effects on Newcomer Adjustments. Academy of Management Journal, 39: 149-178

Atuahene-Gima, K. 2003. The Effects of Centrifugal and Centripetal Forces on Products Development Speed and Quality: How does Problem Solving Matter? Academy of Management Journal, 46: 359-373

Autio, E., Sapienza, H.J., \& Almeida, J.G. 2000. Effects of Age at Entry, Knowledge Intensity, and Imitability on International Growth. Academy of Management Journal, 43: 909-924

Bahrami, H., \& Evans, S. 1987. Stratocracy in High Technology Firms. California Management Review, 30: 51-66.

Camerer, C., \& Vepsalainen, A. 1988. The Economic Efficiency of Corporate Culture. Strategic Management Journal, 9: 115-126

Campion, M.A., Cheraskin, L., \& Stevens, M.J. 1994. Career-related Antecedents and Outcomes of Job Rotation. Academy of Management Journal, 37: 1518-1542 
Cardinal, L.B. 2001. Technological Innovation in the Pharmaceutical Industry: The Use of Organizational Control in Managing Research and Development. Organization Science, 12: $19-36$

Chao, G.T., O’Leary-Kelly, A.M., Wolf, S., Klein, H.J., \& Gardner, P.D. 1994. Organizational Socialization: Its content and Consequences. Journal of Applied Psychology, 79: 730-743

Cockburn, I., Henderson, R., \& Stern, S. 2000. Untangling the Origins of Competitive Advantage. Strategic Management Journal, 21: 1123-1146

Cohen, M.D., \& Bacdayan, P. 1994. Organizational Routines are Stored as Procedural Memory. Organization Science, 5: 554-568

Cohen, W., \& Levinthal, D. 1990. Absorptive Capacity: A new Perspective on Learning and Innovation. Administrative Science Quarterly, 35: 128-152

Daft, R.L., \& Lengel, R.H. 1986. Organizational Information Requirements, Media Richness and Structural Design. Management Science, 32: 554-571

Daft, R.L., \& Macintosh, N.B. 1981. A Tentative Exploration into the amount and Equivocality of Information Processing in Organizational Work Units. Administrative Science Quarterly, 26: $207-224$

Desphandé, R., \& Zaltman, G. 1982. Factors affecting the use of Market Research Information: A Path Analysis. Journal of Marketing Research, 19: 14-31

Dewar, R.D., Whetten, D.A., \& Boje, D. 1980. An Examination of the Reliability and Validity of the Aiken and Hage Scales of Centralization, Formalization, and Task Routiness, Administrative Science Quarterly, 25: 120-128

Dietz, J., Pugh, S.D., \& Wiley, J.W. 2004. Service Climate Effects on Customer Attitudes: An Examination of Boundary Conditions. Academy of Management Journal, 47: 81-92

Dill, W.R. 1958. Environments as an Influence on Managerial Autonomy. Administrative Science Quarterly, 2: 409-443 
Dougherty, D. 1992. Interpretive Barriers to Successful Product Innovation in Large Firms. Organization Science, 3: 179-202

Egelhoff, W.G. 1991. Information-Processing Theory and the Multinational Enterprise. Journal of International Business Studies, 22: 341-368

Eisenhardt, K.M., \& Martin, J.A. 2000. Dynamic Capabilities: What are they? Strategic Management Journal, 21: 1105-1121

Feldman, D.C. 1981. The Multiple Socialization of Organization Members. Academy of Management Review, 6: 309-318

Fisher, C.D. 1986. Organizational Socialization: An Integrative Review. Research in Personnel and Human Resource Management, 4: 101-145

Galbraith, J.R., 1973. Designing Complex Organizations. Reading: Addison-Wesley

Galunic, D.C., \& Rodan, S. 1998. Resource Recombinations in the Firm: Knowledge Structures and the Potential for Schumpeterian Innovation. Strategic Management Journal, 19: $1193-1201$

Gersick, C.J.G., \& Hackman, J.R. 1990. Habitual Routines in Task-Performing Groups. Organizational Behavior and Human Decision Processes, 47: 65-97

Gibson, C.B., \& Birkinshaw, J. 2004. The Antecedents, Consequences, and Mediating Role of Organizational Ambidexterity. Academy of Management Journal, 47: 209-226

Grant, E.S., \& Bush, A.J. 1996. Salesforce Socialization Tactics: Building Organizational Value Congruence. Journal of Personal Selling \& Sales Management, 3: 17-32

Grant, R.M. 1996. Prospering in Dynamically-competitive Environments: Organizational capability as Knowledge Creation. Organization Science, 7: 375-387.

Gupta, A.K., \& Govindarajan, V. 2000. Knowledge Flows within Multinational Corporations. Strategic Management Journal, 21: 473-496 
Hage, J., \& Aiken, M. 1967. Program Change and Organizational Properties: A Comparative Analysis. American Journal of Sociology, 72: 503-519

Hage, J., \& Aiken, M. 1969. Routine Technology, Social Structure, and Organization Goals. Administrative Science Quarterly, 14: 366-376

Hansen, G.S., \& Wernerfelt, B. 1989. Determinants of Firm Performance: The Relative Importance of Economic and Organizational Factors. Strategic Management Journal, 10: $399-411$

Hansen, M.T. 1999. The Search-Transfer Problem: The Role of Weak Ties in Sharing Knowledge across Organization Subunits. Administrative Science Quarterly, 44: 82-111

Henderson, R., \& Cockburn, I. 1994. Measuring Competence? Exploring Firm Effects in Pharmaceutical Research. Strategic Management Journal, 15: 63-84

James, L.R., Demaree, R.G., \& Wolf G. 1993. $\mathrm{R}_{\mathrm{wg}}$ : An Assessment of Within-Group Interrater Agreement. Journal of Applied Psychology, 78: 306-309

Janis, I.L. 1982. Groupthink. Boston: Houghton Mifflin

Jaworski, B.J., \& Kohli, A.K. 1993. Market Orientation: Antecedents and Consequences. Journal of Marketing, 57: 53-70

Jones, A.P., Johnson, L.A., Butler, M.C., \& Main, D.S. 1983. Apples and Oranges: An Empirical Comparison of Commonly Used Indices of Interrater Agreement. Academy of Management Journal, 26: 507-519

Jones, G.R. 1986. Socialization tactics, Self Efficacy, and Newcomer Adjustments to Organizations. Academy of Management Journal, 29: 262-279

Khandwalla, P.N. 1977. Design of Organizations. New York: Harcourt Brace Jovanovich Kogut, B., \& Zander, U. 1992. Knowledge of the Firm, Combinative Capabilities, and the Replication of Technology. Organization Science, 3: 383-397 
Kotha, S., \& Nair, A. 1995. Strategy and Environment as Determinants of Performance: Evidence from the Japanese Machine Tool Industry. Strategic Management Journal, 16: $497-518$

Lane, P.J., Koka, B., \& Pathak, S. 2002. A Thematic Analysis and Critical Assessment of Absorptive Capacity Research. Paper presented at the Annual Academy of Management Meeting, Denver, $\mathrm{CO}$

Lane, P.J., \& Lubatkin, M. 1998. Relative Absorptive Capacity and Interorganizational Learning. Strategic Management Journal, 19: 461-477

Lane, P.J., Salk, J.E., \& Lyles, A. 2001. IJV Learning and Performance. Strategic Management Journal, 22: 1139-1161

Lin, X., \& Germain, R. 2003. Organizational Structure, Context, Customer Orientation, and Performance: Lessons from Chinese State-owned Enterprises. Strategic Management Journal, 24: 1131-1151

Lyles, M.A., \& Salk, J.E. 1996. Knowledge Acquisition from foreign Parents in International Joint-ventures. Journal of International Business Studies, 27: 905-927

Lyles, M.A., \& Schwenk, C.R. 1992. Top Management, Strategy and Organizational Knowledge Structures. Journal of Management Studies, 29:155-174

March, J.G., \& Simon, H.A. 1958. Organizations. John Wiley, New York

Matusik, S.F. 2002. An Empirical Investigation of Firm Public and Private Knowledge. Strategic Management Journal, 23: 457-467

Matusik, S.F., \& Hill, C.W.L. 1998. The Utilization of Contingent Work, Knowledge Creation, and Competitive Advantage. Academy of Management Review, 23: 680-697

McGrath, R.G. 2001. Exploratory Learning, Innovative Capacity, and Managerial Oversight. Academy of Management Journal, 44: 118-131 
Morrison, E.W. 2002. Newcomers' Relationships: The Role of Social Network Ties during Socialization. Academy of Management Journal, 45: 1149-1160

Mowery, D.C., Oxley, J.E., \& Silverman, B.S. 1996. Strategic Alliances and Interfirm Knowledge Transfer. Strategic Management Journal, 17: 77-91

Mumford, M.D. 2000. Managing Creative People: Strategies and Tactics for Innovation. Human Resource Management Review, 10: 313-351

Nahapiet, J., \& Ghoshal, S. 1998. Social Capital, Intellectual Capital, and the Organizational Advantage. Academy of Management Review, 23: 242-266

Neter, J., Wasserman, W., \& Kutner, M.H. 1990. Applied Linear Statistical Models. Homewood, IL: Irwin

Noe, R.A., \& Ford, J.K. 1992. Emerging Issues and New Directions for Training Research. In G.R. Ferris \& K.M. Rowland (Eds.), Research in Personnel and Human Resources Management, 10: 345-384. Greenwich: JAI Press

Pennings, J.M., \& Harianto, F. 1992. The Diffusion of Technological Innovation in the Commercial Banking Industry. Strategic Management Journal, 13: 29-46.

Perrow, C. 1967. A Framework for the Comparative Analysis of Organizations. American Sociological Review, 32: 194-208

Pierce, J.L., \& Delbecq, A.L. 1977. Organization Structure, Individual Attitudes and Innovation. Academy of Management Review, 2: 27-37.

Podsakoff, P.M., \& Organ, D.W. 1986. Self-reports in Organization Research: Problems and Prospects. Journal of Management, 40: 308-338

Randall, D.M. 1987. Commitment and the Organization: The Organization Man Revisited. Academy of Management Review, 12: 460-471

Rindfleisch, A., \& Moorman, C. 2001. The Acquisition and Utilization of Information in New Product Alliances: A Strength-of-Ties Perspective. Journal of Marketing, 65: 1-18 
Rowley, T., Behrens, D., \& Krackhardt, D. 2000. Redundant Governance Structures: An Analysis of Structural and Relational Embeddedness in the Steel and Semiconductor Industries. Strategic Management Journal, 21: 369-386

Sethi, R., Smith, D.C., \& Park, C.W. 2001. Cross-Functional Product Development Teams, Creativity, and the Innovativeness of New Consumer Products. Journal of Marketing Research, 38: 73-85

Sheremata, W.A. 2000. Centrifugal and Centripetal Forces in Radical New Product Development under Time Pressure. Academy of Management Review, 25: 389-408

Siggelkow, N. 2002. Evolution toward Fit. Administrative Science Quarterly, 47: 125-159

Sorensen, J.B., \& Stuart, T.E. 2000. Aging, Obsolescence, and Organizational Innovation. Administrative Science Quarterly, 45: 81-112

Subramaniam, M., \& Venkatraman, N. 2001. Determinants of Transnational New Product Development Capability: Testing the Influence of Transferring and Deploying Tacit Overseas Knowledge. Strategic Management Journal, 22: 359-378

Szulanski, G. 1996. Exploring Internal Stickiness: Impediments to the Transfer of Best Practices within the firm. Strategic Management Journal, 17: 27-44

Teece, D.J., Pisano, G., \& Shuen, A. 1997. Dynamic Capabilities and Strategic Management. Strategic Management Journal, 18: 509-533

Tsai, W. 2001. Knowledge Transfer in Intra-organizational Networks: Effects of Network Position and Absorptive Capacity on Business Unit Innovation and Performance. Academy of Management Journal, 44: 996-1004

Van den Bosch, F.A.J., Van Wijk, R., \& Volberda, H.W. 2003. Absorptive Capacity: Antecedents, Models, and Outcomes. In Easterby-Smith, M. \& Lyles, M.A. (eds), Handbook of Organizational Learning and Knowledge Management (pp. 278-301). Oxford: Blackwell Publishing 
Van den Bosch, F.A.J., Volberda, H.W., \& De Boer, M. 1999. Coevolution of Firm Absorptive

Capacity and Knowledge Environment: Organizational Forms and Combinative

Capabilities. Organization Science, 10: 551-568

Van Maanen, J., \& Schein, E.H. 1979. Toward a Theory of Organizational Socialization. In

B.M. Staw (Ed.), Research in Organizational Behavior, 1: 209-264. Greenwich: JAI Press

Verona, G. 1999. A Resource-based View of Product Development. Academy of Management

Review, 24: 132-142

Volberda, H.W. 1996. Toward the Flexible Form: How to Remain Vital in Hypercompetitive Environments. Organization Science, 7: 359-374

Volberda, H.W. 1998. Building the Flexible Firm: How to Remain Competitive. Oxford University Press, Oxford

Volberda, H.W., \& Van Bruggen, G.H. 1997. Environmental Turbulence: A Look into its

Dimensionality. NOBO Onderzoeksdag 1997, Enschede

Weick, K.E. 1979. The Social Psychology of Organizing. Reading: Addison-Wesley

Withey, M., Daft, R.L., \& Cooper, W.H. 1983. Measures of Perrow's Work Unit Technology:

An Empirical Assessment and a New Scale. Academy of Management Journal, 26: 45-63

Zahra, S.A., \& George, G. 2002. Absorptive Capacity: A Review, Reconceptualization, and

Extension. Academy of Management Review, 27: 185-203

Zaltman, G., Duncan, R., \& Holbek, J. 1973. Innovations and Organizations. New York:

Wiley

Zander, U., \& Kogut, B. 1995. Knowledge and the Speed of the Transfer and Imitation of Organizational Capabilities: An Empirical Test. Organization Science, 6: 76-92

Zollo, M.M., \& Winter, S.G. 2002. Deliberate Learning and the Evolution of Dynamic

Capabilities. Organization Science, 13: 339-351 
TABLE 1

Means, Standard Deviations, and Correlations ${ }^{\mathrm{a}}$

\begin{tabular}{|c|c|c|c|c|c|c|c|c|c|c|c|c|c|c|c|c|c|c|c|c|c|}
\hline & Mean & St. dev & (1) & (2) & (3) & (4) & (5) & (6) & (7) & $(8)$ & (9) & $(10)$ & $(11)$ & $(12)$ & (13) & (14) & $(15)$ & $(16)$ & (17) & (18) & (19) \\
\hline (1) Acquisition & 3.58 & 1.24 & $(.79)$ & & & & & & & & & & & & & & & & & & \\
\hline (2) Assimilation & 4.74 & 1.13 & .28 & $(.76)$ & & & & & & & & & & & & & & & & & \\
\hline (3) Transformation & 4.61 & 0.83 & .35 & .50 & $(.72)$ & & & & & & & & & & & & & & & & \\
\hline (4) Exploitation & 5.26 & 0.72 & .07 & .40 & .55 & $(.71)$ & & & & & & & & & & & & & & & \\
\hline (5) Cross-functional Interfaces & 4.39 & 1.18 & .20 & .17 & .14 & .07 & -- & & & & & & & & & & & & & & \\
\hline (6) Participation & 3.87 & 1.05 & .31 & .10 & .17 & .01 & .17 & $(.79)$ & & & & & & & & & & & & & \\
\hline (7) Job rotation & 2.18 & 1.08 & .20 & .14 & .14 & .05 & .26 & .11 & $(.77)$ & & & & & & & & & & & & \\
\hline (8) Formalization & 5.53 & 0.74 & -.03 & .11 & .20 & .38 & .02 & -.11 & -.04 & $(.73)$ & & & & & & & & & & & \\
\hline (9) Routinization & 3.26 & 0.97 & -.31 & -.20 & -.23 & -.08 & -.06 & -.16 & .01 & -.02 & $(.73)$ & & & & & & & & & & \\
\hline (10) Connectedness & 5.60 & 0.78 & .16 & .27 & .32 & .31 & .09 & .04 & .02 & .14 & -.15 & $(.74)$ & & & & & & & & & \\
\hline (11) Socialization tactics & 4.56 & 0.72 & .02 & .13 & .28 & .39 & .14 & .03 & .20 & .28 & .06 & .13 & $(.75)$ & & & & & & & & \\
\hline (12) Unit size ${ }^{b}$ & 1.44 & 0.27 & -.18 & -.18 & -.20 & -.11 & .20 & -.12 & .19 & -.03 & .16 & -.13 & .06 & -- & & & & & & & \\
\hline (13) Branch size ${ }^{b}$ & 2.10 & 0.18 & .02 & -.00 & .06 & -.03 & .08 & -.09 & .10 & .01 & -.04 & .03 & .10 & .34 & -- & & & & & & \\
\hline (14) Unit age & 3.23 & 2.35 & -.12 & -.01 & .02 & -.01 & -.09 & -.07 & -.07 & .02 & .10 & .09 & -.01 & .00 & -.12 & -- & & & & & \\
\hline (15) Unit client focus & 0.42 & 0.50 & .06 & -.01 & -.08 & -.09 & .12 & -.01 & -.07 & -.15 & -.07 & -.01 & -.04 & .11 & -.02 & .01 & -- & & & & \\
\hline (16) Past performance unit & 102.92 & 24.64 & .11 & .09 & .05 & .00 & -.02 & -.01 & .01 & -.02 & -.05 & .00 & .03 & -.01 & -.07 & -.05 & -.01 & -- & & & \\
\hline (17) Past performance branch & 103.20 & 30.31 & -.01 & -.02 & .04 & .04 & -.14 & -.05 & -.07 & -.03 & -.03 & .02 & .06 & .05 & .01 & .06 & -.06 & .19 & -- & & \\
\hline (18) Urban/rural unit location & 0.54 & 0.50 & .02 & .01 & .00 & -.02 & .02 & -.13 & .11 & -.03 & -.03 & .06 & -.03 & .15 & .40 & -.06 & .03 & -.15 & -.06 & -- & \\
\hline (19) Environmental dynamism & 4.29 & 1.19 & .13 & .17 & .13 & .06 & .01 & .04 & .15 & -.02 & -.13 & .11 & .04 & -.05 & .21 & -.02 & -.11 & .03 & .05 & .18 & $(.75)$ \\
\hline
\end{tabular}

\footnotetext{
${ }^{\mathrm{a}} \mathrm{n}=462$. Numbers in parentheses on the diagonal are Cronbach's alphas of the composite scales. Correlations above I.09| are significant at $\mathrm{p}<.05$.
}

${ }^{\mathrm{b}} \log$ number of full-time employees 
TABLE 2

Results of Hierarchical Regression Analyses: Effects of Organizational Antecedents on Potential and Realized Absorptive Capacity ${ }^{\mathrm{a}}$

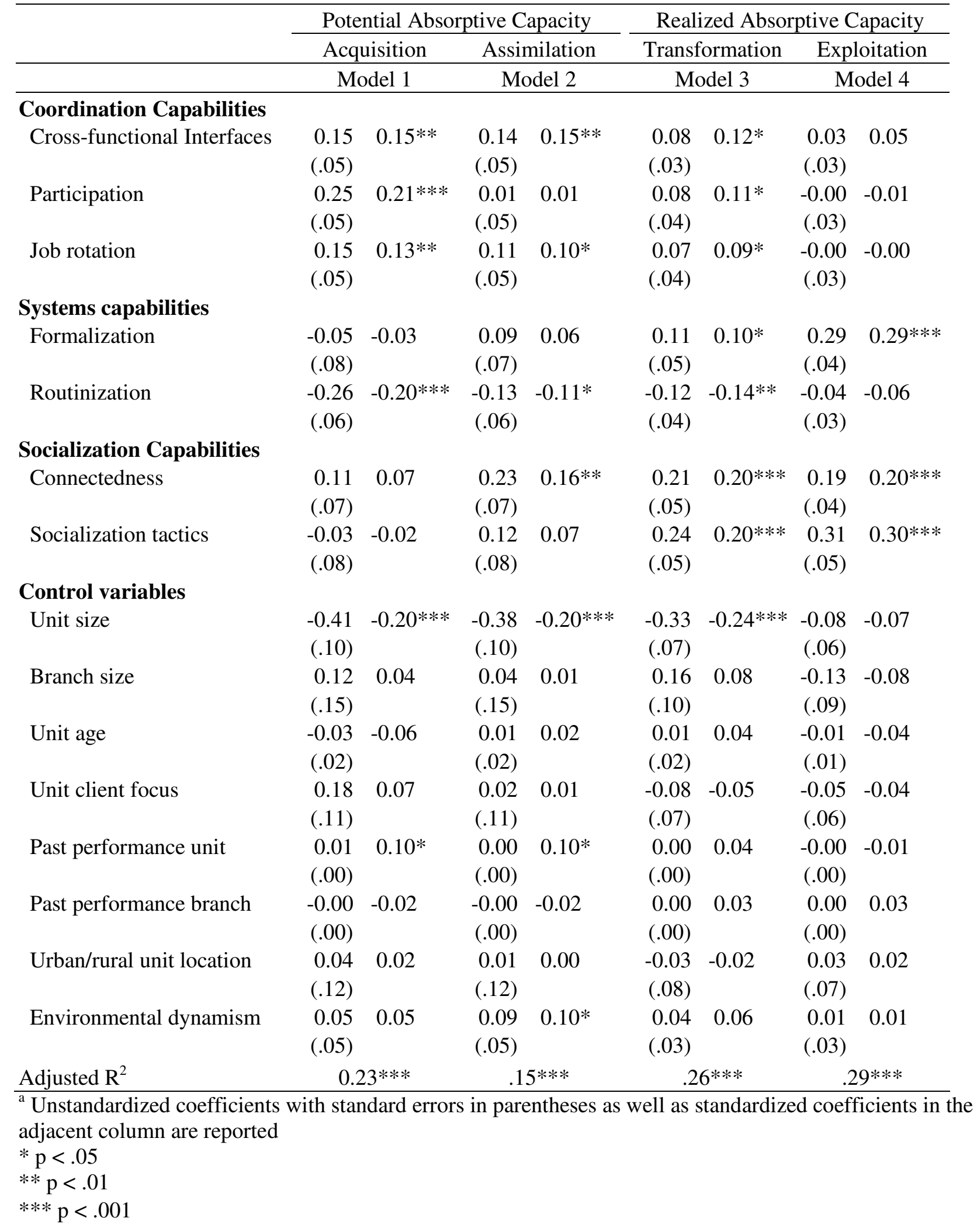




\section{APPENDIX -Scales and Items of Potential and Realized Absorptive Capacity ${ }^{a}$}

\begin{tabular}{|c|c|}
\hline Construct & Items \\
\hline \multicolumn{2}{|c|}{ Potential Absorptive Capacity } \\
\hline Acquisition & $\begin{array}{l}\text { Our unit has frequent interactions with corporate headquarters to acquire new knowledge } \\
\text { Employees of our unit regularly visit other branches } \\
\text { We collect industry information through informal means (e.g. lunch with industry friends, talks with trade partners) } \\
\text { Other divisions of our company are hardly visited }{ }^{\mathrm{b}} \\
\text { Our unit periodically organizes special meetings with customers or third parties to acquire new knowledge } \\
\text { Employees regularly approach third parties such as accountants, consultants, or tax consultants }\end{array}$ \\
\hline Assimilation & $\begin{array}{l}\text { We are slow to recognize shifts in our market (e.g. competition, regulation, demography) }{ }^{\circledR}{ }^{b} \\
\text { New opportunities to serve our clients are quickly understood } \\
\text { We quickly analyze and interpret changing market demands }\end{array}$ \\
\hline \multicolumn{2}{|c|}{ Realized Absorptive Capacity } \\
\hline Transformation & $\begin{array}{l}\text { Our unit regularly considers the consequences of changing market demands in terms of new products and services } \\
\text { Employees record and store newly acquired knowledge for future reference } \\
\text { Our unit quickly recognizes the usefulness of new external knowledge to existing knowledge } \\
\text { Employees hardly share practical experiences } ₫ \\
\text { We laboriously grasp the opportunities for our unit from new external knowledge }{ }^{\circledR} \\
\text { Our unit periodically meets to discuss consequences of market trends and new product development }\end{array}$ \\
\hline Exploitation & $\begin{array}{l}\text { It is clearly known how activities within our unit should be performed } \\
\text { Client complaints fall on deaf ears in our unit } \AA^{b} \\
\text { Our unit has a clear division of roles and responsibilities } \\
\text { We constantly consider how to better exploit knowledge } \\
\text { Our unit has difficulty implementing new products and services }{ }^{\circledR} \\
\text { Employees have a common language regarding our products and services }{ }^{c}\end{array}$ \\
\hline
\end{tabular}

\footnotetext{
a All items are measured on a 7-point scale with 1 "Strongly disagree" to 7 "Strongly agree", ® means reversed coded item

${ }^{\mathrm{b}}$ Item adapted from Jaworski and Kohli (1993)

${ }^{\mathrm{c}}$ Item adapted from Szulanski (1996)
} 
Justin J.P. Jansen is assistant Professor in Strategic Management at the Rotterdam School of Management, Erasmus University Rotterdam, The Netherlands. His current research interests include strategic change, organizational learning, strategic management of innovation in SMEs, and (corporate) entrepreneurship.

Frans A.J. van den Bosch is Professor of Management of Organization - Environment Interfaces at the Rotterdam School of Management, Erasmus University Rotterdam, The Netherlands. He received his PhD from Leyden University. His current research interests include managerial and knowledge-based theories of the firm, strategic renewal, co-evolutionary theory building, corporate governance, and corporate responsiveness.

Henk W. Volberda is Professor of Strategic Management and Business Policy and Chairman of the Department of Strategic Management \& Business Environment of the Rotterdam School of Management, Erasmus University Rotterdam, The Netherlands. He obtained his $\mathrm{PhD}$ cum laude in Business Administration at the University of Groningen. His research focuses on strategic renewal and innovation, strategic flexibility, hypercompetition and new organizational forms, coevolution of firms and industries, and knowledge flows and absorptive capacity. 


\section{Publications in the Report Series Research* in Management}

\section{ERIM Research Program: "Strategy and Entrepreneurship"}

2005

Reciprocity of Knowledge Flows in Internal Network Forms of Organizing

Raymond van Wijk, Frans A.J. van den Bosch, Henk W. Volberda and Sander M. Heinhuis

ERS-2005-024-STR

http://hdl.handle.net/1765/6552

Managing Potential and Realized Absorptive Capacity: How do Organizational Antecedents matter? Justin J.P. Jansen, Frans A.J. van den Bosch, Henk W. Volberda

ERS-2005-025-STR

http://hdl.handle.net/1765/6550

How Knowledge Accumulation Changed the Competitive Advantage of Strategy Consulting Firms*

Frans A.J. van den Bosch, Marc G. Baaij and Henk W. Volberda

ERS-2005-026-STR

http://hdl.handle.net/1765/6553

* A complete overview of the ERIM Report Series Research in Management: https://ep.eur.nl/handle/1765/1

ERIM Research Programs:

LIS Business Processes, Logistics and Information Systems

ORG Organizing for Performance

MKT Marketing

F\&A Finance and Accounting

STR Strategy and Entrepreneurship 